FILOZOFIA

Roč. 75, 2020, č. 3

DOI: https://doi.org/10.31577/filozofia.2020.75.3.4

\title{
PLATÓNOV SOKRATES A PROBLEMATIKA ANTROPOLOGICKÉHO OBRATU
}

FRANTIŠEK ŠKVRNDA, Katedra medzinárodných politických vzt’ahov Ekonomickej univerzity $\mathrm{v}$ Bratislave, Bratislava, SR

ZUZANA ZELINOVÁ, Katedra filozofie a dejín filozofie Univerzity Komenského v Bratislave, Bratislava, SR

ŠKVRNDA, F., ZELINOVÁ, Z.: Plato's Socrates and the Problems of Anthropological Turn

FILOZOFIA, 75, 2020, No 3, pp. $212-223$

The following study scrutinizes Plato's account of Socrates' intellectual biography in the dialogue Phaedo. This account is crucial for the interpretation of Socrates' philosophy as an ,antropological turn“, that separates Presocratic philosophical tradition from its Socratic counterpart. The first part of this study exposes Plato's account in Phaedo as exaggerated and inaccurate treatment of Presocratic - especially Anaxagorean - philosophy. Study then proceeds to pinpoint common features between Plato's Socrates and Anaxagoreans. Subsequently, extensive Anaxagorean contaminations are found in Platonic theoretical (metaphysics, cosmology) as well as practical (ethics, philosophy as way of life) philosophy. The study concludes that Socrates' anthropological turn is in fact an artificial product of Plato's philosophy that calls for further examination.

Keywords: Plato - Socrates - Anthropological turn - Developmentalism - Anaxagoras - Diogenes of Apollonia - Nous - Cosmology - Ethics - Atopos

\section{Úvod}

Postava Sokrata z Atén a jeho filozofická činnost' predstavujú z hl'adiska dejín filozofie jeden z najdôležitejších orientačných bodov. Sokrates charakterizuje zrod novej filozofickej paradigmy, ktorá sa začína takzvaným antropologickým obratom. Sokrates bol údajne prvým filozofom, ktorý zniesol filozofiu z neba na zem a namiesto prírodovedných a logických skúmaní sa začal zaoberat' otázkami typu čo je to cnost', čo je to spravodlivost', čo je to múdrost', atd'. ${ }^{1}$

\footnotetext{
${ }^{1} \mathrm{~K}$,zneseniu filozofie z neba na zem“ pozri klasickú formuláciu u Cicera (Tusc. Disp. V. 10; Acad. I. 15), a tiež mierne pozmenenú variáciu (namiesto prírodovedného skúmania sa spomína Pytagorov a Empedoklov „mysticizmus“ a ,poverčivost"“) u Plutarcha (De Gen. Socr. 580b2 - 3). Moderní bádatelia Sokrata označujú za tvorcu základov novej vedy ako vedy o človeku (Berland 1986).
} 
Obraz Sokrata ako revolučného filozofa je vel'mi starý a siaha až k prvej generácii jeho žiakov, menovite ku Xenofónovi a Platónovi. Títo autori zhodne tvrdia, že Sokrates kritizoval staršiu generáciu prírodných filozofov a ich skúmania považoval len za stratu času. ${ }^{2}$ Ak sa pozrieme na tieto správy detailnejšie, tak zistíme, že nie sú až také jednoznačné. Tieto referáty sa rozchádzajú v jednom zásadnom detaile. Zatial' čo v Xenofónových Spomienkach a v Platónovej Apológii sa píše, že Sokrates sa prírodovedným otázkam nikdy nevenoval, tak v Platónovom Faidónovi nachádzame zaujímavú „autobiografickúu pasáž (porov. Phaed. 96a - 100b), v ktorej sa Sokrates priznáva, že v mladosti sa týmto otázkam intenzívne venoval. Platónov výklad vo Faidónovi sa zdá historicky dôveryhodnejší, pretože Sokratove väzby na staršiu tradíciu prírodných myslitel'ov zaznamenávajú viacerí starovekí spisovatelia. Na prvom mieste môžeme uviest' Aristofanovu komédiu Oblaky, v ktorej Sokrates vystupuje ako horlivý prívrženec filozofickej sekty anaxagorovcov, najmladšej predsokratovskej iónskej vetvy filozofie, ktorá prekvitala v Aténach za vlády Perikla. ${ }^{3} \mathrm{Na}$ druhom mieste by sme mohli uviest' správy antických doxografov, ktorí nás informujú, že Sokrates bol od svojich sedemnástich rokov žiakom a spoločníkom ${ }^{4}$ Anaxagorovho žiaka Archelaa z Atén. ${ }^{5}$

$\mathrm{Na}$ jednej strane teda Sokrates a limine odmieta prírodovedné skúmania a celú predchádzajúcu filozofickú tradíciu, na druhej strane však vystupuje ako nasledovatel' anaxagorovcov. Tieto na prvý pohl'ad protirečivé svedectvá viedli väčšinu bádatel'ov $\mathrm{k}$ riešeniu, ktoré sa v dejinách filozofie označuje ako „developmentalistické“. ${ }^{6}$ Developmentalizmus predpokladá, že osobnost' filozofa sa vyvíja v čase, že prekonáva rôzne zmeny a v priebehu života mení svoje (nielen) filozofické zásady a názory. Tak sa v dôsledku Platónovho Faidóna Sokratova filozofická kariéra rozdelila na dve obdobia:

(1) rané štádium, v ktorom bol Sokrates pod vplyvom anaxagorovcov

\footnotetext{
${ }^{2}$ Pozri bližšie Platón, Apol. 19b - d; Phd. 96a - 99a; Xenofón, Mem. I. 10 - 14 a IV. 7, 5 - 6.

${ }^{3}$ Vander Waerdt (1994) vidí v názoroch Aristofanovho Sokrata myšlienky Diogena z Apollónie, Betegh (2013) v nich identifikoval aj vplyv iných anaxagorovcov (Archelaos z Atén a sám Anaxagoras).

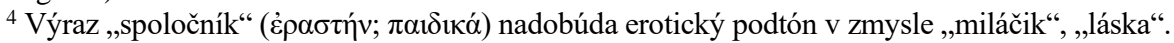

5 Túto správu nachádzame u viacerých doxografov. Porov. Diogenes Laertský (Vit. II 16, 19, 23) a zlomky z Porfýriových Dejín filozofie (fr. 52a - b Wehrli), kde sa ako pôvodcovia tejto správy udávajú Aristoxenos z Tarenta (4. stor. pred Kristom) a Ión z Chiu (5. stor. pred Kristom). Väčšina súčasných bádatel'ov pokladá tieto zlomky za autentické a historicky hodnoverné. Pozri Huffman (2012, 261), Fletcher (2007).

${ }^{6}$ Najznámejším autorom, ktorý využil princípy „analytického developmentalizmu“ na odlíšenie názorov historického Sokrata od tých Platónových, je Vlastos (1991, 45 - 80). Vlastosove závery sú ešte aj dnes mnohými bádatel’mi prijímané. Pozri Cepko $(2019,29)$.
} 
(2) neskoršie štádium, ked' Sokrates razí novú cestu vlastnej originálnej filozofii, zameranej na hl'adanie etických definícií a cnostného života. ${ }^{7}$

V predloženej štúdii sa pokúsime vymedzit’ voči záverom, ktoré vyplývajú z Platónovho Faidóna, a spochybnit’ tak celú developmentalistickú interpretáciu Sokratovej filozofie. Nazdávame sa, že takáto interpretácia je vo svetle dostupných správ a popisov zo všetkých Platónových dialógov neudržatel'ná a je potrebná jej revízia. Naším ciel'om bude prostredníctvom kontextuálnej analýzy ${ }^{8}$ Platónových dialógov poukázat' na tie momenty, $v$ ktorých sa postava Sokrata, alebo filozofické názory tejto postavy, dostávajú do blízkosti anaxagorovskej myšlienkovej tradície a v ktorých môžeme vidiet' výraznú afinitu sokratovsko-platónskej a predsokratovskej tradície myslenia.

Naše úvahy vzhl’adom na problematiku takzvanej sokratovskej otázky obmedzíme výhradne na platónske dialógy, pretože si nenárokujeme predkladat žiadne jej komplexnejšie riešenie. ${ }^{9}$ Sokrates pre nás v tejto štúdii jednoducho predstavuje hovorcu platónskych dialógov a takpovediac prvého muža celej tradície myslenia, prostredníctvom ktorej Platón a jeho najbližší spoločníci explikovali svoje filozofické ideály a postoje. Čitatel'ov, ktorí by namietali, že postava Sokrata nadobúda naprieč spektrom platónskych dialógov diametrálne odlišné vlastnosti a že z tohto dôvodu treba rozlišovat' medzi „ranými“, „tranzitívnymi“ a inými skupinami v rámci celého platónskeho korpusu, odkazujeme na práce bádatel'ov, ktorí takýto stylometrický prístup ku kategorizácii Platónových diel dekonštruovali a poukázali na jeho interpretačnú neudržatel'nost'. ${ }^{10}$

\section{Faidón}

Našu analýzu začneme vyššie spomenutou autobiografickou pasážou z Faidóna. Najprv sa zameriame na prehnanú zjednodušenost', s ktorou Platón zhŕňa celú dovtedajšiu

\footnotetext{
${ }^{7}$ Developmentalistická interpretácia Sokratovho myslenia a osobnosti je už dlhý čas communis opinio. Pozri bližšie Taylor (1917, 17); Guthrie (1971, 101 - 102); McPherran (1996, 73); Janko (2006, 59); Porubjak (2012, 87); Suvák (2015, 37 - 38).

${ }^{8} \mathrm{~K}$ metóde kontextuálnej analýzy ako základného interpretačného princípu v historiografii antickej filozofie pozri bližšie Brickhouse \& Smith $(2000,5)$.

${ }^{9}$ K problematike historického Sokrata pozri bližšie Waterfield (2013) a v súčasnosti Dorion (2018), ktorý predkladá model metódy komparatívnej exegézy jednotlivých sokratovských autorov (najmä Platóna a Xenofóna) ako najplauzibilnejší spôsob zodpovedania sokratovskej otázky. V našej štúdii však pod postavou „Sokrata“ budeme rozumiet' len platónsku postavu Sokrata, a nie komparatívny amalgám Platónovho, Xenofónovho, Aristofanovho, prípadne aj Aristotelovho či Aristoxenovho Sokrata.

${ }^{10}$ Spomedzi mnohých autorov uvedieme slová Holgera Thesleffa, podl’a ktorého „o relatívnej a absolútnej chronológii tzv. raných, stredných a semiautentických dialógov nemožno tvrdit’ nič určité" (Thesleff 2009, 399).
} 
tradíciu prírodnej filozofie. ${ }^{11}$ Starší myslitelia sa podl’a Sokrata mýlili v jednej dôležitej veci - za arché sveta uvádzali akúsi mechanickú mysel' (voṽs), ktorá všetky veci roztriedila a určila im ich prirodzené miesto vo svete, alebo iného „Titana“, ktorý podopiera svet ako akýsi stíp alebo podpera. Takéto teórie podl’a Sokrata nemôžu vysvetlit' to najdôležitejšie - prečo je svet usporiadaný tak, ako je, a prečo je najlepšie, aby bol usporiadaný tak, ako je. Inými slovami, Sokrates hladá teleologické vysvetlenie, účel usporiadania celej prírody a kozmu. Stažuje sa, že výkladom starších mys-

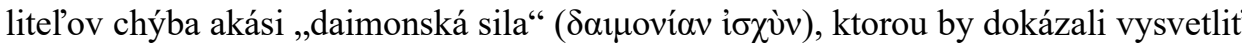
tento účel, ako aj to, prečo je to také krásne, dobré a spravodlivé (Phd. 99c). Podl’a Sokrata teda arché nemôže byt' len prírodným elementom alebo akýmsi mechanickým „prvým hýbatel'om“. Musí byt' aj čímsi, čo je obdarené rozumom a dušou. Sokrates sa tak od predchádzajúcej tradície dištancuje pre jej redukcionistický výklad, ktorý redukuje onú daimonskú silu len na jej mechanické či empirické atribúty.

$\mathrm{Na}$ tejto kritike je zvláštne najmä to, či je skutočne možné predsokratovským výkladom a teológiám podsunút' takúto mechanicko-empirickú redukciu. V prípade Empedoklea z Akragantu ${ }^{12}$ alebo Herakleita $\mathrm{z}$ Efezu $^{13}$ sa takáto možnost' javí ako krajne nepravdepodobná. S ostatnými postavami je to viac-menej podobné: viacerí historici filozofie upozorňujú na skutočnost', že prakticky všetky predsokratovské výklady podstaty sveta nadobúdali nielen mechanický, ale aj výrazne panpsychický teda daimonský - rozmer. Arché si u nich podržiava základné atribúty homérskych bohov, teda nesmrtel'nost', večnost', myslenie, oduševnenost' a snahu usporiadat' svet čo možno najdokonalejšie. ${ }^{14}$

${ }^{11}$ K Platónovmu nekorektnému zaobchádzaniu so staršou myšlienkovou tradíciou pozri bližšie Kingsley (1995, 88 - 95).

${ }^{12}$ Podl'a Empedokla boli ,prvými“ mnohovlnné more, zem, vlhká para, Titan a aithér (DK 31 B 38), no tieto sily sú s vysokou pravdepodobnost'ou totožné s homérskymi božstvami. Porovnaj $D K 31 \mathrm{~B}$ 6, kde sa aithér stotožňuje s Diom, zem s Hérou a vlhká para s Nestidou (pozri bližšie Kingsley 1995, 13 - 68). Stotožnenie jednotlivých bohov s elementmi je diskutabilnou otázkou (pozri Vítek 2001, 89 - 139), hoci je nespochybnitel'né, že Empedokles prírodné elementy stotožňoval s daimónmi ako oduševnenými silami. Podobne sú aj základné „pohybové príčiny“ Empedoklovej koz-

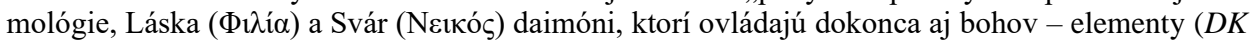
31 B $16-17$ a $D K 31$ B 71). Zlomok $D K 31$ B 115 spomína, že počiatok sveta držia v rukách akýsi „výrok Osudu“ a rôzne prísahy, čo eo ipso vylučuje ich mechanickú prirodzenost' - výroky a prísahy musia byt' niekým vypovedané a garantované.

${ }^{13}$ Pozri bližšie zlomok $D K 22$ B 32: Zápas ako počiatok sveta je „ono múdre“, ktoré sa chce aj nechce nazývat' Zénom (Diom). Porovnaj tiež $D K 22$ B 50, 67, 80, 93, 108. Herakleitova koncepcia večne živého ohňa ( $\pi$ õ $\alpha \dot{\alpha} \varepsilon i \zeta \zeta \omega o v)$ tak predstavuje skôr „najkvalitnejšiu formu hmoty“ (Sweeney 1972, 73), ktorá odkazuje k zoroastriánskym koncepciám ohňa ako oduševneného princípu / božstva (pozri West 2015, 440).

${ }^{14}$ Takýto názor vyjadrujú napríklad Burkert (1985, 305 - 311); Gerson (1990, 1 - 32) a Tzamalikos (2016, 618). Prvý a druhý autor ponúkajú všeobecný pohl'ad na predsokratovskú filozofiu (od Thaléta po Anaxagora), pozri Gerson (1990,31): „Je celkom prirodzené čítat' Anaxagora ako niekoho, kto postuloval jedinečnú archē, nazývanú nous, ktorá je priliehavo nazývaná ,bohom'...". Tretí autor píše, 
Platónov výklad predsokratovskej filozofie vo Faidónovi je problematický najmä v momente, ked’ Sokrates začne spomínat' Anaxagora (97b). Výčitky, ktoré mu Sokrates adresuje, sa pri detailnejšom čítaní zachovaných zlomkov Anaxagora a jeho stúpencov, zdajú byt' úplne nemiestne. Ako príklad uvedieme zlomky Diogena z Apollónie, Métrodora z Lampsaku a text papyru z Derveni. ${ }^{15}$ Diogenés z Apollónie píše, že by „nebolo možné, aby bol celok sveta usporiadaný v takej náležitej miere bez pôsobenia

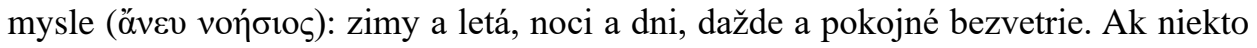
chce uvažovat' aj o ostatných veciach, objaví, že sú usporiadané najkrajšie, ako je

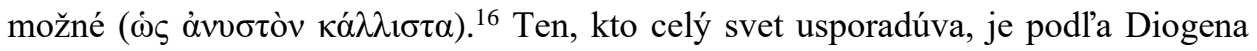
vzduch, no tento vzduch je zároveň aj boh (Zeus) a mysel', teda Sokratom hl'adaná daimónska sila: „Zdá sa mi, že to, čo má myslenie, je l'ud'mi označované ako vzduch. Týmto je všetko riadené a ovládané. Toto sa mi totiž zdá, že je boh. Všetko prestupuje, všetko usporadúva, nachádza sa vo všetkom. Nie je nič, na čom by to nemalo účast'."17 Ďalší anaxagorovec, Metrodóros z Lampsaku, dokonca stotožňoval bohov s l'udskými orgánmi či končatinami. ${ }^{18}$ Papyrus z Derveni zase uvádza, že ak by boh „,nechcel ( $\varepsilon i$

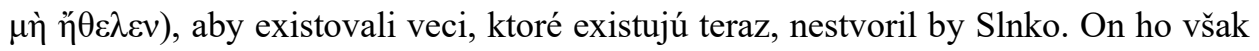
stvoril presne takej vel'kosti a kvality, ako bolo vysvetlené na začiatku tohto výkladu.“"19 Ak sa napokon pozrieme na Aristotelove referáty o Anaxagorovi, tak zistíme, že Mysel' označil za pôvodcu krásy ( $\kappa \alpha \lambda \tilde{\omega} \varsigma)$ a správnosti (ỏ $\theta \tilde{\omega} \varsigma)$, pričom Aristoteles v tejto súvislosti uvádza, že pojem mysle Anaxagoras často zamieňa za pojem „duše“ a v ich rozlíšení nie je dôsledný. ${ }^{20}$

Tento kontext, $\mathrm{v}$ ktorom sa pohybujú predsokratovské - predovšetkým anaxagorovské - úvahy o arché, pripúšt’a mechanistickú interpretáciu mysle ako arché len vo vel'mi obmedzenej miere. Na jednej strane môžeme čítat' vyššie uvedené zlomky spôsobom, ako to robí Platón - vzduch je skutočne základom myslenia, čiže je to, in senso strictu, vzduch, čo v nás myslí. Na druhej strane je však tento vzduch bohom, čo vy-

\footnotetext{
že boha ako všeriadiacu mysel', ktorá sa nedá zredukovat' len na mechanické princípy, museli predpokladat' okrem Anaxagora už Táles, Xenofanes aj Pytagoras.

${ }^{15}$ Hoci autor papyrusu z Derveni nie je známy, bádatelia jednoznačne identifikujú jeho rozsiahle anaxagorovské pozadie (pozri Janko 1997, no najmä Betegh 2004).

${ }^{16}$ DK 64 B 3. Všetky preklady z gréckeho jazyka, pokial' nie je uvedené inak, pochádzajú od autorov tejto štúdie.

${ }^{17} D K 64$ B 5 a $D K 64$ A 8 (Zeus = mysel' = vzduch).

${ }^{18}$ DK 64 A 4, 6: Demeter = pečeň, Dionýzos = slezina, Apollón = žlčník, Aténa $=$ ruky. Bohov spájal s l'udskými orgánmi a končatinami zrejme aj d'alší predsokratovec Demokritos z Abdér (pozri DK 68 B 301).

${ }^{19}$ Pozri col. XXV. V úvode spisu papyrusu Derveni je uvedený Herakleitov citát „Slnko má šírku l’udskej stopy“ (col. IV; DK 22 B 3). Text papyrusu, ako aj jeho pagináciu, ktorej sa pridržiavame, pozri v Hladký (2010) a Laks \& Most (2016).

${ }^{20}$ DK 59 A $100 / 1$ a $100 / 2$.
} 
tvára usporiadanost' a účelovost', krásu a správnost' a disponuje vlastnou vôl'ou. Ovel'a pravdepodobnejšia sa zdá možnost', že mechanicita je len jeden z atribútov alebo módov, ktorými sa daimónska sila prejavuje v prírode ako v zmyslovom svete. Platón tento atribút vo Faidónovi výrazne hyperbolizuje, pravdepodobne preto, aby ho mohol použit' ako takzvaný straw man argument, pomocou ktorého môže lepšie artikulovat' vlastný pohl'ad na pertraktovaný problém nesmrtel'nosti l'udskej duše. ${ }^{21}$

\section{Kratylos}

Pri čítaní d’alších dialógov sa vzt'ah medzi anaxagorovcami a Platónovým Sokratom dostáva do celkom inej polohy. Sokrates sa na jednom mieste pýta svojho spoločníka Her-

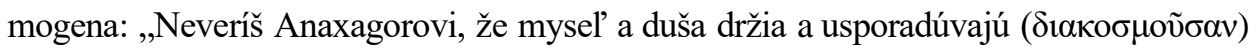
všetky ostatné veci v prírode?“ (Crat. 400a) $)^{22}$ Na prvý pohl’ad vyznieva otázka ironicky a triviálne. Odpoved' na ňu je samozrejmá a Hermogenes na ňu aj tak odpovedá („Samozrejme, že verím.“). Po tejto odpovedi však neprichádza žiadny Sokratov elenchos, nič, čím by Sokrates Hermogena zneistil, vyvrátil jeho odpoved’ či iným spôsobom ju problematizoval. Práve naopak, dialóg nadobúda podobu systematickej a etymologickej expozície pravých mien bohov. Tak sú Uranos a Kronos názvy pre „čistú a nezmiešanú mysel' ( „meteorológov“, za ktorými moderní bádatelia tušia anaxagorovcov, ${ }^{24}$ výraz „nebesá

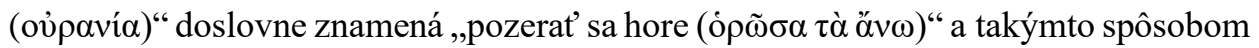
nadobúdat' čistú, nezmiešanú mysel', teda rozumnost' a umiernenost'. ${ }^{25}$ Zeus ako potomok čistej mysle označuje spravodlivost', teda to, „čo preniká všetkými ostatnými

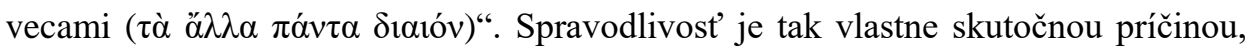

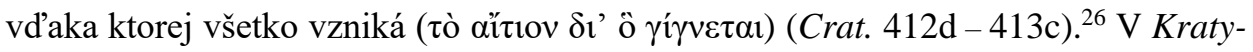
lovi sa Sokrates štylizuje do pozície anaxagorovca, ktorý je schopný prostredníctvom etymologického výkladu popísat' podstatu bohov ako nebeských telies a zároveň garantov spravodlivosti. Zdá sa, akoby Sokrates doplńnal anaxagorovské výklady o etický prvok, no spôsob, akým to robí, je taký unikátny, že v ňom nevidno hranicu toho,

${ }^{21}$ Sokratovu autobiografickú pasáž zasadzuje do širšieho kontextu Platónovej filozofie práca Burger $(1984,135-144)$.

22 Preklad J. Špaňár.

${ }^{23}$ Vel'mi podobnú terminológiu obsahuje Anaxagorov zlomok DK 59 A 100/2: ,jednoduchá, čistá

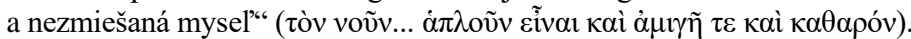

${ }^{24}$ Pozri Baxter (1992, 160 - 163); Sedley (2003, 92).

${ }^{25}$ Pozri Platón, Crat. 396b-c. Papyrus z Derveni taktiež stotožňuje Krona s myslou, col. XIV. Baxter $(1992,130)$ navrhuje, aby sa čast' Diogenovho zlomku $D K 64$ A 19, kde sa hovorí o tom, že l’udia

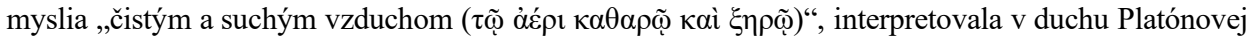
etymologizácie boha Urana, čím vlastne poukazuje na fakt, že autor papyrusu Derveni a Diogenes z Apollónie reprezentujú tú istú myšlienkovú tradíciu.

${ }^{26}$ Sokrates tu explicitne pripisuje Anaxagorovi presvedčenie, že to, čo je spravodlivé, je mysel'. Ostatné definície sú však takisto anaxagorovské, pozri Baxter (1992, 128 - 129). 
kde výklad ešte sleduje anaxagorovskú terminológiu a kde už prechádza do sokratovskej podoby.

Etymológie z Kratyla niektorí odborníci interpretujú len ako Platónovu ironickú kritiku anaxagorovcov a typ výkladov, aké obsahuje papyrus z Derveni. ${ }^{27}$ Podl’a nás je však sotva predstavitel'né a zdôvodnitel'né, prečo by malo íst' skôr o iróniu a kritiku, ako o expozíciu anaxagorovských teórií. Vo Faidónovi je napríklad miesto, kam duša odchádza po oddelení od tela, charakterizované významovo rovnakou terminológiou ako Anaxagorova kozmická mysel' / duša (

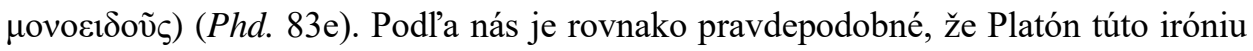
využíva skôr na to, aby ňou zakryl a odl'ahčil skutočnost', že nadväzuje na anaxagorovskú tradíciu a preberá jej teologicko-kozmologické koncepcie. Inými slovami, Platón iróniou zakrýva fakt, že jadro jeho metafyziky je v skutočnosti sformované na anaxagorovskom základe. ${ }^{28}$

\section{Filebos, Epinomis, Timaios}

Pri čítaní d'alších dialógov sa toto podozrenie pomaly premieňa na konštatáciu. Vo Filebovi Sokrates, tentoraz bez akéhokol'vek náznaku irónie, spomína, že „mysel' je

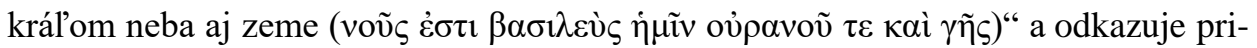
tom na jednohlasnú symfóniu „mudrcov“, ktorí stotožnili Dia s král'ovskou mysl'ou a dušou, ktorá usporiadala celý viditel'ný aj myslitel'ný kozmos (Phil. 28c). V platón-

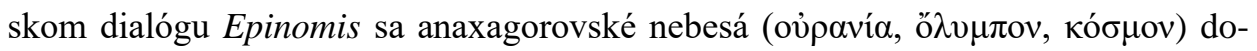
konca označujú za najvyššie božstvo, ktoré musia všetci uctievat' a ktoré dáva l'ud'om

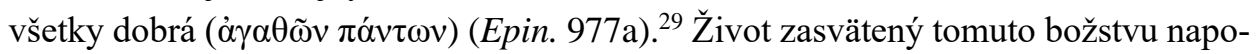
kon l’ud’om prináša všetky dary „božstva“, pričom slovo „božstvo“ je totožné so slo-

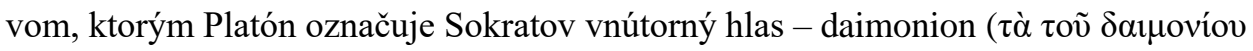
$\sigma u ́ \mu \pi \alpha v \tau \alpha)$ (Epin. 992d). O tom, akým spôsobom sa toto darovanie vlastne odohráva, nás informuje dialóg Timaios: sledovanie krúživých pohybov nebeských telies nastol'uje harmóniu krúživých pohybov duše - človek sa tak pripodobňuje bohom do najvyššej možnej miery, do akej je toho schopný: učí sa pri tom matematiku, geometriu a astronómiu. ${ }^{30}$ Platónova metafyzika tak v neskorej fáze jeho života dospela k prak-

${ }^{27}$ Pozri Baxter (1992, 160 - 163), ktorý akcentuje Platónovu kritiku anaxagorovcov a celej staršej tradície. K definícii Platónovej irónii pozri bližšie klasickú štúdiu Vlastosa (1991, 21 - 44): iróniou sa rozumie vedomé zamieňanie nevedomosti za múdrost'.

${ }^{28}$ Pozri Tzamalikos $(2016,527$ - 536, 615, 624 - 625), ktorý túto možnost’ uvádza a dokladá na viacerých miestach.

${ }^{29}$ Nebesá tu nadobúdajú anaxagorovské charakteristiky najmä cez podobnost' s Diogenovým vzdu-

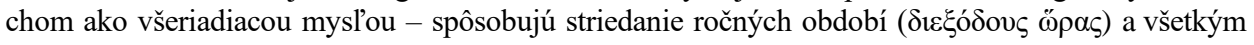
veciam poskytujú výživu (

${ }^{30}$ Túto problematiku detailnejšie rozoberá štúdia Sedley $(2010,118$ - 127). 
ticky totožnej koncepcii teoretického života, akú tradícia pripisuje Anaxagorovi: cie-

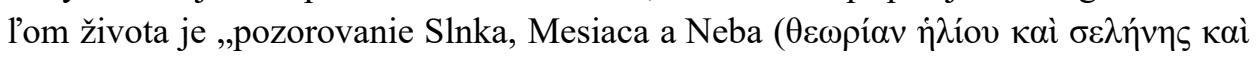
oủpavoũ) “. ${ }^{31}$

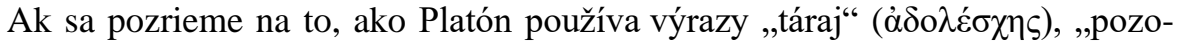

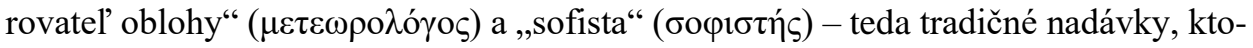
rými Sokrata častuje napríklad Aristofanés - tak zistíme, že v špecifických prípadoch ich používa skôr ako superlatívy. Styk s „tárajom“ a „sofistom“ Anaxagorom spravil z Perikla lepšieho človeka, „tárajom“ a „sofistom“ je však pre Platóna aj Sokrates (Phaedr. 269e; Crat. 401b). ${ }^{32} \mathrm{~V}$ podobenstve o lodi z Ústavy sa dokonca píše, že skutočného kormidelníka (fillozofa) budú l'udia označovat' za „neužitočného pozoro-

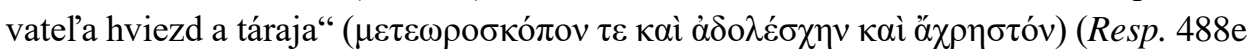
- 489a). Toto je osud, ktorý postretol rovnako Anaxagora, ako aj Sokrata.

\section{Theaitétos, Apológia}

Odkaz Anaxagora sa začína objavovat' nielen v Platónovej metafyzike, ale dokonca aj $\mathrm{v}$ jeho praktickej filozofii. V Theaitétovi Sokrates popisuje pravého filozofa termínom „,̌udák“ (ả tó $0 \varsigma)(T h t .75 \mathrm{c}-\mathrm{d}){ }^{33}$ Ide o osobu, ktorej vonkajšok je zanedbaný, ktorá sa vôbec nestará o svoje súkromné záležitosti či hmotné imanie a ktorou druhí l'udia opovrhujú. V dialógu Hippias Väčši však nachádzame týmto termínom označeného samého Anaxagora ([Platón], Hipp. Ma. 281c). Doxografickej tradícii bol Anaxagorás ako „čudák“ dobre známy. Podobne ako Sokrates, aj on zanedbával svoju domácnost' (DK 59 A 13/1), pričom údajne hovorieval, že skutočne blaženým nie je ten, kto je bohatý, ani ten, na koho sa usmiala štastena - skôr ním bude nejaký „čudák“ (à tó alebo štýl, ktorý ústi do vnútornej neotrasitel'nosti a vyrovnanosti. Sokrates a Anaxagoras vedia, že po smrti už vôbec nezáleží na tom, ako budú pochovaní. ${ }^{34}$ Obidvaja sú triezvi, umiernení a takmer vôbec sa nesmejú. ${ }^{35}$ Podl'a Anaxagora a Sokrata je

\footnotetext{
${ }^{31}$ Diogenés Laertský, Vit. II 10. Aristoteles uvádza Anaxagorov výrok vel’mi podobne: $\tau$ õ $\theta \varepsilon \omega \rho \tilde{\eta} \sigma \alpha \iota$

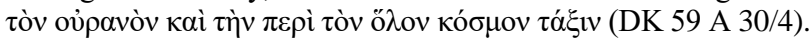

${ }^{32}$ Pozri bližšie Tzamalikos $(2016,172)$ a Taylor $(2006,157$ - 168). Druhý bádatel' uvádza, že prakticky všetky definície sofistu v Platónovom rovnomennom dialógu (Sofistés) sa vzt’ahujú aj na Sokrata: Sokrates je lovec boháčov, ktorý od nich však neberie peniaze; podobá sa podomovému obchodníkovi, ktorý druhým ponúka svoju múdrost' (teda. uvedomovanie si vlastnej nevedomosti); je slovný bojovník, ktorý inkasuje aj rozdáva údery; je takisto aj čarodejník, ktorý dokáže druhých l'udí paralyzovat' svojimi zariekadlami; v prvom rade je však ,vznešeným“ sofistom, ktorý očist'uje duše.

${ }^{33}$ Ide o vlastnost', ktorá patrí medzi najfrekventovanejšie popisy Platónovho Sokrata, porovnaj Destrée $(2005,77)$.

${ }^{34}$ Pozri $D K 59$ A 34a a Platón (Phd. 115c).

${ }^{35}$ DK 59 A 21 (Anaxagora nikdy nevideli smiat' sa, a ani nedával druhým dôvod na úsmev; Euripides ako Anaxagorov žiak sa takisto nesmial a nežartoval ani pri víne). Porovnaj Sokratovu vlastnost',,vznešenej chôdze a gúl'ania očí, ako aj osobitý postoj k pitiu, ktoré spomínajú Aristofanes (Nub. 362) aj
} 
l'udský rozum vo všeobecnosti príliš slabý a z tohto dôvodu nemôže preniknút' $\mathrm{k}$ pravej podstate vecí. ${ }^{36}$ Obidvaja majú dokonca aj dar veštenia - aj ked', pravda, s tým rozdielom, že Anaxagorove veštby sú prevažne meteorologické prognózy. ${ }^{37}$ Obidvaja vychovávajú významných politikov a obidvaja sú napokon obvinení zo zavádzania nových božstiev a dobrovol'ne odchádzajú zo života. ${ }^{38}$

Pre d’alšiu komparáciu je zaujímavý aj postoj k smrti, ktorý Sokrates formuluje v Platónovej Apológii: „Existuje však vel'ká nádej, že je to niečo dobré. Smrt' je totiž jedno z dvoch - bud' je to ako nebytie a mítvy nemá o ničom žiadny pocit, alebo je to - podla toho, čo sa rozpráva - akýsi prechod duše a prest'ahovanie z tohto miesta na iné. A ak teda po smrti človek už nič nevníma, ale je to ako spánok, ked' sa nám ani nič nesníva, bola by smrt' obdivuhodným ziskom“ (Apol. 40c - d). Podobný názor vyjadruje aj jeden sýrsky zlomok, pripisovaný práve Anaxagorovi: „Smrt', ktorá sa na prvý pohl'ad zdá lud’om horká, je v skutočnosti niečím krásnym. Dodáva pokoj starobe, ktorá už postráda sily. V mladosti utišuje všetky bolesti, v detstve oslobodzuje od všetkého otroctva a služieb, ktoré musíme vykonávat' pre druhých. Smrt' oslobodzuje aj dlžníkov od svojich veritel'ov. Nemali by sme nariekat' nad niečím, čo je nevyhnutné, pretože smútok to nedokáže odvrátit'. Dobrá nálada však dokáže túto chvíl'kovú nevyhnutnost' zakryt' - netrpí predsa ten, kto si kráti chvíl'u čakaním v prístave. A ak je pre niekoho pohl'ad na smrt' odporný, nech si na chvíl'u zatvorí oči. Vidíte, aká je smrt' krásna; smrt', po ktorej volajú zmrzačení, t’ažko chorí l’udia, ako aj tí, ktorí sú na mučidlách. Toto je dôkaz, aký pokojný a príjemný je život v podsvetí“ (DK 59 B 23). ${ }^{39}$

Platón (Symp. 221b). Jediným momentom, ked' sa Sokrates v Platónových dialógoch smeje, je moment

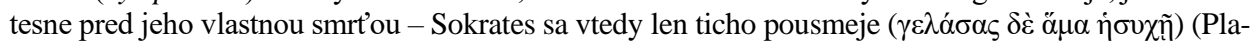
tón, Phd. 115c).

${ }^{36}$ DK 59 A 28, 66, 95. Toto môže byt' skutočný dôvod, prečo Anaxagoras nepopísal Mysel' inak ako mechanicky - obmedzil sa len na jej prejavy vo svete, pretože jej esencia je nespoznatel’ná. Porovnaj zlomok $D K 59$ A 48/5 od Cicera, ktorý píše, že podl'a Anaxagora sa svetová Mysel' vymyká sile našeho myslenia a rozumu.

${ }^{37}$ DK 59 A 1, 6, 10, 42. Jedna z Anaxagorových predpovedí sa však netýkala nebeských fenoménov, ale záležitosti nie nepodobnej predpovediam Sokratovho daimonia: Anaxagoras údajne veštil, že spadne nejaký dom (DK 59 A 6/2). Okrem toho, v platónskom dialógu Epinomis nadobúda meteorologický charakter aj daimonion ako oblast' sprostredkovatel'ov medzi vyššími božstvami a l'ud'mi -

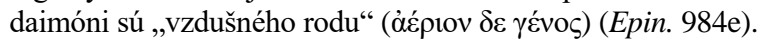

${ }^{38}$ Otázka súdneho procesu s Anaxagorom je kontroverzná - mnohí bádatelia pokladajú správy neskorších doxografov o Anaxagorovom procese za historické, niektorí však vyjadrujú skepticizmus, poukazujúc na nedostatočnú textovú evidenciu (pozri bližšie Herschbell 1982). K otázke dobrovol'ného odchodu zo života pozri $D K 59$ A 3 (Anaxagoras zomiera v dôsledku toho, že sa zdrží jedla), ako aj skutočnosti, že v Platónovom Kritónovi sa Sokrates poddá nespravodlivému rozsudku aj napriek tomu, že mu priatelia ponúkajú možnost' utiect' z väzenia. Sokrates sa rozhodol odíst' zo života ani nie tak pre legálne udelený trest, ale kvôli svojmu daimoniu (Platón, Apol. 40b). Podobne referuje o Sokratovom rozhodnutí dobrovol'ne odíst' zo života aj Xenofón (Apol. $7-8)$.

${ }^{39}$ Preložené podl’a anglického prekladu (fr. R 36) v zbierke Laks \& Most (2016, 180 - 181). 
Podobnosti medzi Anaxagorom a Platónovým Sokratom nadobúdajú z hl'adiska praktickej filozofie, respektíve etiky, relatívne komplexný charakter. Obaja stelesňujú predstavu filozofa, ktorý si je vedomý svojej vlastnej obmedzenosti, stráni sa kontaktu so spoločnost'ou, alebo sa voči nej vymedzuje zvláštnymi návykmi a asketickým spôsobom života. ${ }^{40}$ Filozofický život predpokladá štúdium prejavovania sa bohov vo viditel'nom svete, teda zameranie sa na špecificky poňatú astronómiu ako teológiu.

\section{Záver}

Podobnosti medzi Platónovým Sokratom a anaxagorovskou tradíciou myslenia viedli niektorých bádatel'ov k tomu, aby Platónov portrét Sokrata označili za mýtus a legendu, pričom z pozadia vystupuje práve postava Anaxagora ${ }^{41}$ Pri detailnejšom pohl'ade na vzt’ah medzi Anaxagorom a Platónovým Sokratom sa skutočne ocitáme $\mathrm{v}$ problematickej, ba dokonca až aporetickej situácii, ked' máme interpretovat' fakt, že v údajných „,raných“ a „stredných“ dialógoch sa postava Sokrata svojimi životnými zásadami a postojmi približuje Anaxagorovi, zatial’ čo v „neskorých“ a ,semiautentických“ dialógoch sa myšlienky Anaxagora zrkadlia v Platónových metafyzických, kozmologických a teologických úvahách?

V Platónovom podaní tak Sokratovo znesenie filozofie z neba na zem predpokladá, že $v$ jednom bode svojho života sa odvrátil od učitel'ov a predchodcov, ktorých v mladosti nasledoval. Platónov Sokrates však vykazuje anaxagorovské kontaminácie naprieč spektrom platónskych dialógov (rané, stredné, neskoré). Sokrates ako večne pochybujúci človek, ktorý žije v skromnosti a nebojí sa ani smrti, nedbá, či ním druhí l’udia opovrhujú, alebo sa mu vysmievajú. Nezáleží mu na ničom inom, len na pravde a hl'adaní skutočnej múdrosti - toto všetko bolo znakom tiež iného, staršieho mudrca Anaxagora z Klazomen. Ak máme verit' Platónovej Apológii, tak Sokratovi budú ešte aj na sklonku jeho života žalobcovia vyčítat', že vyznáva anaxagorovské myšlienky o bohoch (Platón, Apol. 26d - e). Je možné, že Sokrates sa neodklonil od svojich učitelov, ale skôr rozvíjal ich odkaz podobným spôsobom, akým budú sokratovci neskôr rozvíjat' ten jeho? Je možné, že autobiografická pasáž z Faidóna je Platónovou iróniou, osobitým spôsobom vyjadrenia faktu, že myšlienky a úvahy Sokratových učitel’ov tvoria základ a východisko jeho vlastnej filozofie?

Ak poodhalíme závoj Platónovho mýtu o Sokratovom radikálnom rozchode s predchádzajúcou myšlienkovou tradíciou, objavuje sa pred nami nový, neznámy obraz tohto mudrca: Sokrates predsokratovec, ktorý rozvíja praktickú etiku v zásade

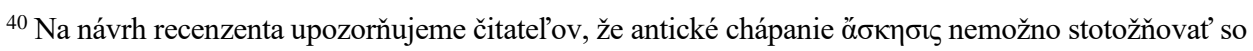
stredovekou askézou.

${ }^{41}$ Pozri bližšie práce Chroust (1957) a Montuori (1981). Títo bádatelia sa však nepokúsili odhalit’ anaxagorovské motívy v platónskych dialógoch systematickým spôsobom, ale ich konštatujú len in passim, akoby mimochodom. 
rovnakým spôsobom, akým to robili jeho učitelia, a ktorý dokonca uctievaním mysteriózneho daimonia podržiava aj ich prírodovedecké teórie. ${ }^{42} \mathrm{Z}$ Platónových dialógov je zrejmé, že Sokratov obrat k človeku nebol výkonom jedného myslitel'a, a pravdepodobne ani jednej generácie myslitel'ov. Išlo skôr o zložitý a kontinuálny proces, ktorý trval niekol'ko generácií a v symbolickej postave Sokrata našiel svoje najvýraznejšie stelesnenie.

\section{Literatúra}

BAXTER, T. M. S. (1992): The Cratylus. Plato's Critique of Naming. Leiden: Brill.

BERLAND, K. (1986): Bringing Philosophy Down from the Heavens: Socrates and the New Science. Journal of the History of Ideas, 47 (2), 299 - 308.

BETEGH, G. (2004): The Derveni Papyrus. Cosmology, Theology and Interpretation. Cambridge: Cambridge University Press.

BETEGH, G. (2013): Socrate et Archélaos dans les Nuées. In: Laks, A., Saetta Cottone, R. (eds.): Comédie et Philosophie: Socrate et les «présocratiques» dans les Nuées d'Aristophane. Paris: Editions Rue d'Ulm, s. 87 - 106.

BRICKHOUSE, T. C. \& SMITH, N. D. (2000): The Philosophy of Socrates. Boulder: Westwood Press.

BURKERT, W. (1985): Greek Religion. Harvard: Harvard University Press.

CEPKO, J. (2019): Od konfliktu k zdatnosti. Aischinés a sokratovská výchova. Filozofia, 74 (1), 28 - 39. DOI: https://doi.org/10.31577/filozofia.2019.74.1.3.

DESTRÉE, P. (2005): The Daimonion and the Philosophical Mission - Should the Divine Sign Remain Unique to Socrates? Apeiron 38 (2), 63 - 80.

DORION, L.-A. (2018): Comparative Exegesis and the Socratic Problem. In: Danzig, G., Johnson, D., Morrison, D. (eds.): Plato and Xenophon. Comparative Studies. Leiden: Brill, 55 - 70.

FLETCHER, R. (2007): Legwork: Ion's Socrates. In: Jennings, V., Katsaros, A. (eds.): The World of Ion of Chios. Brill: Leiden, 319 - 330.

GERSON, L. P. (1990): God and Greek Philosophy. London: Routledge.

GUTHRIE, W. K. C. (1971): Socrates. Cambridge: Cambridge University Press.

HERSCHBELL, J. P. (1982): Plutarch and Anaxagoras. Illinois Classical Studies, 7 (1), 141 - 158.

HLADKÝ, V. (2010): Papyrus Derveni. Červený Kostelec: Pavel Mervart.

HUFFMAN, C. A. (2012): Aristoxenus' Life of Socrates. In: Huffman, C. A. (ed.): Aristoxenus of Tarentum: Discussion. New Brunswick: Transaction Publishers, $251-281$.

CHROUST, A.-H. (1957). Socrates. The Man and the Myth. The Two Socratic Apologies of Xenophon. London: Routledge \& Kegan Paul.

JANKO, R. (1997): The Physicist as Hierophant: Aristophanes, Socrates and the Autorship of the Derveni Papyrus. Zeitschrift für Papyrologie und Epigraphik, 118, 61 - 94.

JANKO, R. (2006): Socrates the Freethinker. In: Ahbel-Rappe, S., Kamtekar, R. (eds.): A Companion to Socrates. Oxford: Blackwell Publishing Ltd., 48 - 62.

KINGSLEY, P. (1995): Ancient Philosophy, Mystery and Magic. Oxford: Oxford University Press.

LAKS, A., MOST, G. (2016): Early Greek Philosophy. Later Ionian and Athenian Thinkers I. London: Harvard University Press.

McPHERRAN, M. L. (1996): The Religion of Socrates. University Park: Pennsylvania University Press.

${ }^{42}$ Správy o Sokratovi, ktoré nachádzame v spisoch Aristofana a Xenofóna, smerujú k rovnakému záveru - pozri hlavne štvrtú kapitolu prvej knihy Xenofónových Spomienok, kde Sokrates dokazuje existenciu svojho daimonia v intenciách anaxagorovskej noetiky a kozmológie. Detailnejšia analýza a komparatívna exegéza týchto autorov si však vyžaduje širší priestor, než poskytuje táto štúdia. 
MONTUORI, M. (1981): Socrates. Physiology of a Myth. Amsterdam: J. C. Gieben.

PORUBJAK, M. (2012): Sókratés a problém interpretácie dejín filozofie. Filozofia, 67 (1), 83 - 88.

SEDLEY, D. (2003): Plato's Cratylus. New York: Cambridge University Press.

SEDLEY, D. (2010): Připodobnění se bohu jako etický ideál. In: JIRSA, J. (ed.): Rozum, cnosti a duše. Praha: Oikoymenh, 110 - 132 .

SUVÁK, V. (2015): Sókratés a sokratika I. Prešov: Vydavatel'stvo Prešovskej univerzity.

SWEENEY, L. (1972): Infinity in the Presocratics: A Bibliographical and Philosophical Study. Hague: Martinus Nijhoff

TAYLOR, A. E. (1917): Plato's Biography of Socrates. The Proceedings of British Academy VIII, $1-40$.

TAYLOR, C. C. W. (2006): Socrates the Sophist. In: Judson, E., Karasmanis, V. (eds.): Remembering Socrates. Oxford: Oxford University Press, $157-168$.

THESLEFF, H. (2009): Platonic Patterns. A Collection of Studies by Holger Thesleff. Las Vegas: Parmenides Publishing.

TZAMALIKOS, P. (2016): Anaxagoras, Origen and Neoplatonism. Berlin: Walter de Gruyter GmbH.

VLASTOS, G. (1971): The Paradox of Socrates. In: Vlastos, G. (ed.): The philosophy of Socrates. A collection of critical essays. New York: Doubleday \& Company, $1-21$.

VLASTOS, G. (1991): Socrates: ironist and moral philosopher. Cambridge: Cambridge University Press.

VANDER WAERDT, P. (1994): Socrates in the Clouds. In: Vander Waerdt, P. (ed.): The Socratic Movement. Ithaca: Cornell University Press, $48-86$.

VÍTEK, T. (2001): Empedoklés I. Studie. Praha: Rezek.

WATERFIELD, R. (2013): The Quest for the Historical Socrates. In: Bussanich, J., Smith, N. D. (eds.): The Bloomsbury Companion to Socrates. London: Bloomsbury Academic, $1-19$.

WEHRLI, F. (1945): Die Schule des Aristoteles. Aristoxenos. Basle: Benno Schwabe.

WEST, M. L. (2015): The Classical World. In: Stausberg, M., Sohrab-Dinshaw Vevaina, Y., Tessman, A. (eds.): The Wiley Blackwell Companion to Zoroastrianism. West Sussex: John Wiley \& Sons, $437-450$.

Štúdia je súčast'ou riešenia grantovej úlohy VEGA: 1/0864/18 Ad Fontes Cynicorum Socraticorum - pramene a interpretácia sókratovského kynizmu.

František Škvrnda ml.

Katedra medzinárodných politických vzt’ahov

Fakulta medzinárodných vzt’ahov

Ekonomická univerzita v Bratislave

Dolnozemská cesta 1

85235 Bratislava 5

Slovenská republika

e-mail: frantisek.skvrnda2@euba.sk

ORCID-ID: https://orcid.org/0000-0002-2573-3409
Zuzana Zelinová

Katedra filozofie a dejín filozofie

Filozofická fakulta Univerzity Komenského

v Bratislave

Šafárikovo nám. 6

81801 Bratislava 1

Slovenská republika

e-mail: zelinova9@uniba.sk

ORCID-ID: https://orcid.org/0000-0002-5316-8929 